\title{
RANCANG BANGUN SISTEM IRIGASI PEMBIBITAN PENGKONDISIAN LAHAN PADI BERBASIS ATMEGA328 DAN MONITORING JARAK JAUH DENGAN RADIO FREKUENSI $433 \mathrm{MHZ}$
}

\author{
Aly Nur Ariana 1, Zainal Abidin ${ }^{2}$ \\ ${ }^{1)}$ Program Studi Teknik Elektro, Fakultas Teknik, Universitas Islam Lamongan \\ ${ }^{2)}$ Program Studi Teknik Elektro, Fakultas Teknik, Universitas Islam Lamongan \\ E-mail : alefn.rizkiyah@gmail.com ${ }^{1}$, inal9474@gmail.com
}

\begin{abstract}
System of open-close channel or water pipe irrigation is a widely used method. Required a system that can automate the system of irrigation field so that water contribution can be done evenly and enough. As the development of an automatic field irrigation system by utilizing electrode level sensor performance, to open and close the water distribution pipe automatically with the help of ATmega328 microcontroller as the central controller system that will be embedded code-code program that is needed and can be monitored from remotely wirelessly. In this research will discuss how to make an irrigation system based on atmega328 and remote monitoring with $433 \mathrm{mhz}$ radio frequency and how efficient the tool is to influence the water level sensor and soil moisture sensor so that it can work well on the system. In principle the work system of this tool starts from the first Start and then ATMega328 pin initialization reads the soil moisture sensor and water level sensor with LCD display, and sends data to RF transmitter module to send to $R F$ receiver. Making atmega328-based irrigation system and remote monitoring with $433 \mathrm{mhz}$ radio frequency is made by designing tools ranging from microcontrollers, ultrasonic sensors, soil moisture sensors that can create a tool to facilitate farmer in the fields.
\end{abstract}

Keywords : Atmega328, Ultrasonic Sensor, Humidity Sensor, RF $433 \mathrm{Mhz}$

\section{PENDAHULUAN}

Sistem irigasi adalah salah satu faktor penentu keberhasilan dari usaha pertanian. Pengaturan irigasi yang baik harus mampu mendistribusikan air yang dapat mengkondisikan kesuburan tanah dalam jumlah yang cukup tinggi bagi tanaman secara merata, serta meminimalisir adanya genangan air yang berlebihan. Salah satu proses pada sistem irigasi adalah pemberian air irigasi secara manual dengan cara buka tutup saluran atau pipa air irigasi. Sistem buka tutup saluran atau pipa air irigasi secara manual merupakan metode yang banyak digunakan.Diperlukan suatu sistem yang dapat mengotomatisasi sistem irigasi sawah agar pendstribusian air dapat dilakukan secara merata dan cukup. Dari permasalahan tersebut maka penulis memilih penelitian "RANCANG BANGUN SISTEM IRIGASI PEMBIBITAN PENGKONDISIAN LAHAN PADI BERBASIS ATMEGA328 DAN MONITORING JARAK JAUH DENGAN RADIO FREKUENSI 433 MHZ" sebagai pengembangan suatu sistem irigasi sawah otomatis dengan memanfaatkan kinerja sensor elektroda level,untuk membuka dan menutup pipa distribusi air secara otomatis dengan bantuan mikrokontroler ATmega328 sebagai pusat pengendali sistem yang akan ditanamkan code-code program yang diperlukan dan dapat dimonitor dari dari jarak jauh tanpa kabel. Kelebihan dari sistem otomatisasi irigasi sawah ini adalah dapat mengaktifkan dan mematikan pompa air yang menyalurkan air ke sawah secara otomatis dengan melihat keefisienan jumlah debit air, serta dapat memberikan laporan kepada user melalui RF (Radio Frequency) dengan frekuensi $433 \mathrm{MHz}$ apabila terjadi kelebihan atau kekurangan air pada sawah tersebut. 


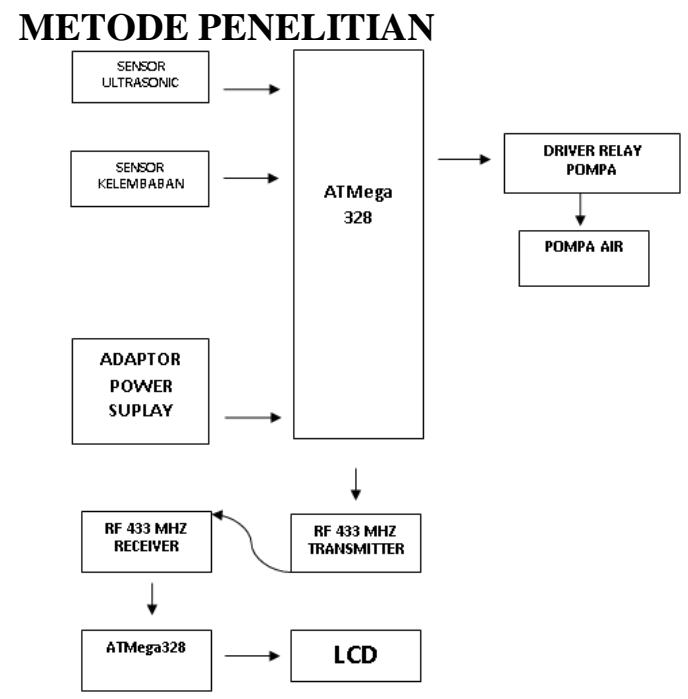

Gambar 2. Digram Blok Perencanaan Alat

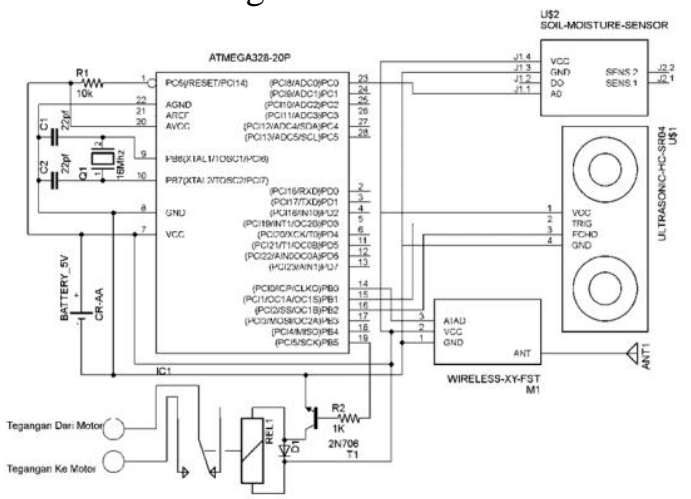

Gambar 3. Skema Perancangan

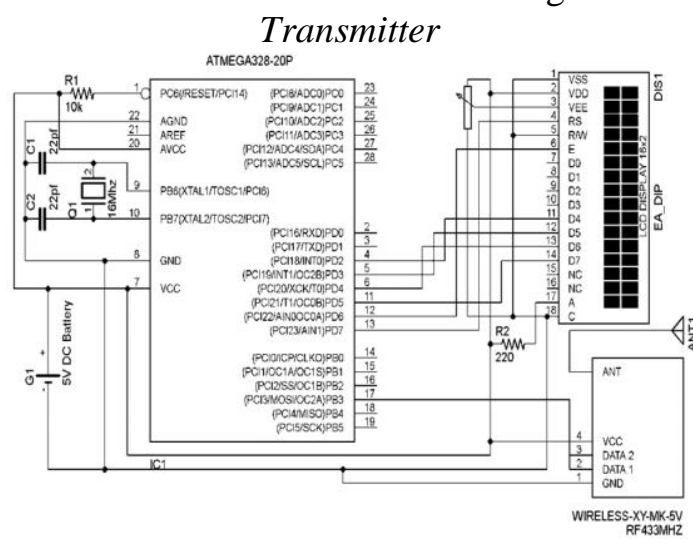

Gambar 4. Skema Perancangan Receiver

Prinsip kerja rancang bangun ini sebagai berikut untuk baterai mensuplai tegangan Arduino dan komponen lainya saat tidak terhubung dengan catu daya dari PLN, dan adaptor untuk pengisian batrei saat kehabisan daya. Sedangkan prinsip kerja sistem, diawali dengan memasukkan data-data yang berhubungan dengan ketinggian air dan kelembaban tanah.Data-data sensorketinggian air dan kelembaban tanah tersebut dimasukkan kedalam mikrokontroller.Data-data yang sudah dimasukkan akan menjadi acuan mikrokontroller untuk menjalankan system.

Jika kondisi air di bawah batas rendah air, maka mikrokontroller akan menjalankan system untuk menyalakan pompa air. Dan jika kondisi ketinggian air melebihi batas yang ditentukan maka mikrokontroller akan memerintah system untuk menghentikan pompa air, mikrokontroller juga bertugas mengirim data ketinggian dan kelembaban melalui Modul RF $433 \mathrm{mHz}$ kepada remot monitor dan begitu seterusnya.

\section{Rancangan Hardware}

Perancangan hardware sistem irigasi ini sesuai dengan namanya menggunakan sistem atmega328 yang akan dikirim melelui radio frekuensi.Alat ini dirancang dengan berbagai alat elektronika seperti power supply yang berfungsi sebagai input tegangan pada alat ini,kemudian ada arduino sebagai otak alat tersebut.Untuk batrei sebagai pengisian sistem kemudian modul RF sebagai pengirim dan penerima data melalui gelombang radio dengan besar frekuensi penghantar tertentu. Adapun sensor moisture sebagai deteksi kelembaban tanah,pompa air digunakan sebagai pemindah air dan sensor ultrasonik sebagai pembaca sensor ketinggian air.

\section{Perancangan Software}

Perancangan software alat sistem irigasi ini memerlukan data sebagai acuan kerja alat yang digunakan. Pengisian data tersebut menggunakan arduino ide sebagai tempat pengisian data dan menyimpannya kemudian data ini akan terbaca oleh atmega 328 dan memerintah komponen seperti sensor dan lainnya sesuai data yg sudah diisi sebelumnya.

\section{HASIL PEMBAHASAN}

Hasil

Dalam hasil ini terdapat beberapa pengujian diantaranya berupa sensor ultrasonic, sensor kelembaban tanah, modul radio frekuensi 433 Mhz, hasil pengujian peragkat lunak dan hasil keseluruhan

\section{Pengujian Rangkaian}

Pengujian rangkaian dilakukan dengan menguji sensor kelembaban, sensor ultrasonic, dan tampilan LCD 16x2 ,kemudian dilanjutkan dengan pengujian untuk mengetahui jarak maksimum transmisi data dengan modul RF $433 \mathrm{MHz}$ baik tanpa halangan maupun dengan halangan. Untuk mensimulasikan variasi 
tegangan, arus, dan tampilan LCD 16x2 dilakukan dengan cara memberikan macam macam tegangan dan beban yang berbeda pada sensor. Untuk mengetahui jarak maksimum transmisi data digunakan variasi catu daya (12 Volt) pada modul RF $433 \mathrm{MHz}$.

\section{Pengujian Sensor Kelembaban Tanah}

Pengujian dilakukan untuk mengetahui rangkaian sensor kelembaban tanah bekerja dengan baik, maka diadakan pengetesan rangakaian sensor kelembaban tanah dengan board Arduino Unoyang menggunakan IC mikrokontroller ATMega328.

Untuk mengetahui ke akuratan sensor kelembaban tanah pengujian tidak hanya dilakukan pada satu objek, berikut adalah data hasil pengukuran dari beberapa objek.

Tabel 1. Tabel Hasil Penguji Sensor Kelebaban tanah

\begin{tabular}{ccc}
\hline Objek yang diukur & \multicolumn{2}{c}{ Hasil Pengukuran } \\
\cline { 2 - 3 } & Moisture Meter (V) & Sensor Kelembaban Arduino (V) \\
\hline Tanah Kering & 157 & 155 \\
\hline Tanah Basah-Kering & 178 & 170 \\
\hline Tanah Basah Air & 182 & 176 \\
\hline
\end{tabular}

\section{Pengujian Rangkaian RF 433 Mhz}

a. Pengujian Transmisi Data Luar Ruangan

Pengujian pertama dilakukan pada tempat terbuka yang memiliki luas kurang lebih 20 meter dan tidak memiliki halangan apapun. Kemudian, pengujian dilakukan dengan memasang rangkaian transmitter dan rangkaian receiver dengan range jarak yang berbeda, mulai dari jarak yang terdekat sampai jarak yang paling jauh. Maka didapatkan hasil pengujian yang peneliti cantumkan dalam bentuk tabel sebagai berikut.

Tabel 2. Tabel Hasil Pengujian Modul RF di Luar Ruangan

\begin{tabular}{cccccc}
\hline $\begin{array}{c}\text { Catu } \\
\text { Daya } \\
\text { Voltmeter } \\
1\end{array}$ & Voltmeter 2 & Larak & Status & Data dikirim & $\begin{array}{c}\text { Data } \\
\text { diterima }\end{array}$ \\
& & & & & \\
& & & & & \\
\hline $\mathbf{1 2}$ Volt & 5 volt & 5 meter & Sukses & 2 & 2 \\
\hline $\mathbf{1 2}$ Volt & 5 volt & 8 meter & Sukses & 2 & 2 \\
\hline $\mathbf{1 2}$ Volt & 5 volt & 10 meter & Sukses & 2 & 2 \\
\hline $\mathbf{1 2}$ Volt & 5 volt & 12 meter & Sukses & 2 & 2 \\
\hline $\mathbf{1 2}$ Volt & 5 volt & 16 meter & Gagal & - & - \\
\hline
\end{tabular}

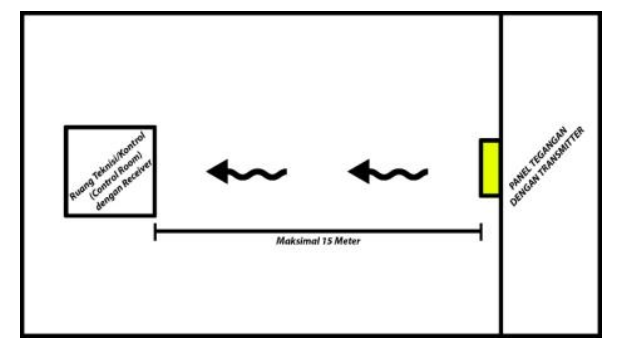

Gambar 5. Ilustrasi Pengaplikasian Jarak Jangkauan Sinyal RF

\section{a. Pengujian Transmisi Data Dalam Ruangan}

Pengujian transmisi data dengan kondisi melalui halangan ini dilakukan didalam bangunan satu lantai yang luasnya beragam dengan ketebalan tembok $\pm 14 \mathrm{~cm}$ dengan material bata, pasir, dan semen dan pada ruangan tersebut terdapat perangkat elektronik lainya. Denah bangunan yang digunakan untuk pengujian alat adalah sebagai berikut:

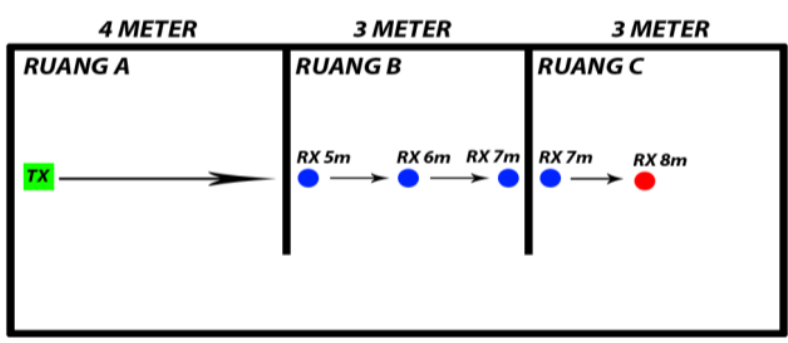

Gambar 6. Denah Pengujian Dalam Ruangan

Bagian transmitter ditempatkan di salah satu ruangan, sedangkan bagian receiver berpindahpindah untuk memberikan beberapa variasi jarak. Transmitter (dilambangkan dengan simbol kotak hijau bertanda Tx) berada di ruang A dengan catu daya 12 Volt untuk memancarkan sinyal, sedangkan receiver (dilambangkan dengan simbol bulat biru bertanda $\mathrm{Rx}$ ) berada di ruang $\mathrm{B}$ menerima data dengan catu daya 12 Volt. Transmitter tetap tak berpindah pada posisinya, sedangkan receiver bergeser menjauh segaris dengan transmitter (ditandai dengan garis panah) untuk memberikan variasi jarak. Posisi bulat merah pada gambar adalah posisi receiver yang mengalami gangguan penerimaan data akibat jarak dan jumlah tembok melebihi jumlah yang dapat ditembus oleh sinyal RF. 
Tabel 3. Hasil Pengujian Transmisi Data dalam Ruangan

\begin{tabular}{|c|c|c|c|c|c|c|c|}
\hline $\begin{array}{l}\text { Po } \\
\text { sisi }\end{array}$ & $\begin{array}{l}\text { Catu } \\
\text { Daya } \\
\text { Voltmeter } \\
1\end{array}$ & $\begin{array}{l}\text { Volt } \\
\text { meter } \\
2\end{array}$ & Jarak & $\begin{array}{c}\text { Jumlah } \\
\text { Halangan } \\
\text { Tembok }\end{array}$ & $\begin{array}{l}\text { Data } \\
\text { dikirim }\end{array}$ & $\begin{array}{l}\text { Data } \\
\text { diteri } \\
\text { ma }\end{array}$ & Status \\
\hline \multirow[t]{3}{*}{1} & 12 Volt & 5 volt & 7 meter & 1 & 2 & 2 & Sukses \\
\hline & 12 Volt & 5 volt & 8 meter & 1 & 2 & 2 & Sukses \\
\hline & 12 Volt & 5 volt & 9 meter & 1 & 2 & 2 & Sukses \\
\hline & 12 Volt & 5 volt & $12 \mathrm{~meter}$ & 2 & 2 & - & Gagal \\
\hline
\end{tabular}

\section{Pengujian Ultrasonic HC-SR04}

Untuk mengetahui ultrasonic HC-SR04 bekerja dengan baik, maka diadakan pengetesan sensor ultrasonic HC-SR04 dengan board Arduino Uno yang menggunakan IC Mikrokontroler ATMega328.

Hasil dari pengujian sensor ultrasonic HC-SR04 dan pengukuran penggaris / meteran menunjukkan bahwa sensor ultrasonic HCSR04 kurang presisi, karena jika sensor mengalami kesalahan sedikit saja (misal: kesalahan tidak benar posisi sensor pembacaan mikrokontroler), maka error yang didapatkan langsung besar,hal ini dapat disimpulkan bahwa sensor ultrasonic tidak dapat digunakan dengan baik.

Tabel 4. Tabel pengujian sensor sensor ultrasonic HC-SR04

\begin{tabular}{ccc}
\hline $\begin{array}{c}\text { Penggaris / } \\
\text { Meteran }\end{array}$ & $\begin{array}{c}\text { Sensor sensor } \\
\text { Ultrasonic HC-SR04 }\end{array}$ & Perbedaan \\
\hline $\mathbf{1 0 , 5} \mathbf{~ c m}$ & $10 \mathrm{~cm}$ & $0,5 \mathrm{~cm}$ \\
& & $0 \mathrm{~cm}$ \\
\hline $\mathbf{7 ~ c m}$ & $7 \mathrm{~cm}$ & \\
& & $0,5 \mathrm{~cm}$
\end{tabular}

\section{Pengujian Sistem Keseluruan}

Pengujian sistem keseluruhan menggunakan air dan tanah, rangkaian transmitter yaitu dua sensor ultrasonic dan dua sensor kelembaban tanah yangdipasang di box miniatur. Untuk mendapatkan nilai tinggi dan kelembaban,kedua sensor dipasang pada miniatur sawah.

Rangkaian kedua yaitu rangkaian receiver yang terdiri dari Arduino Uno R3 dan LCD 16x2 yang berfungsi untuk menampilkan hasil pengukuran nilai tinggi dan kelembaban pada sensor yang ada pada rangkaian transmitter.

Tabel 5. Pengujian alat secara keseluruhan

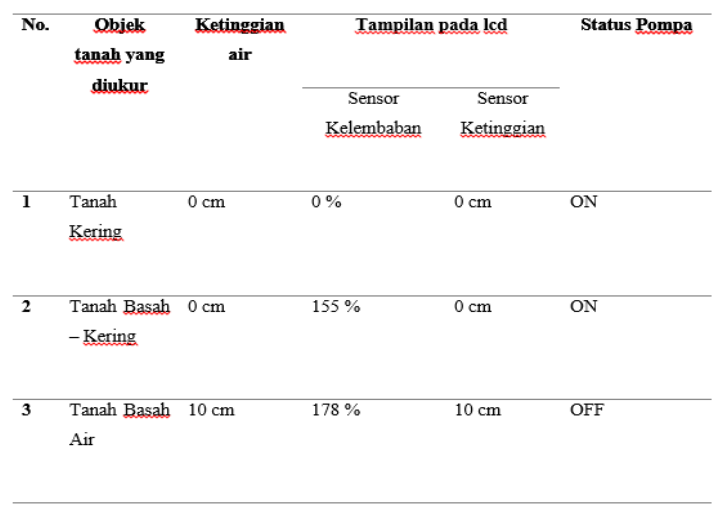

Tabel 6. Pengujian alat perbagian

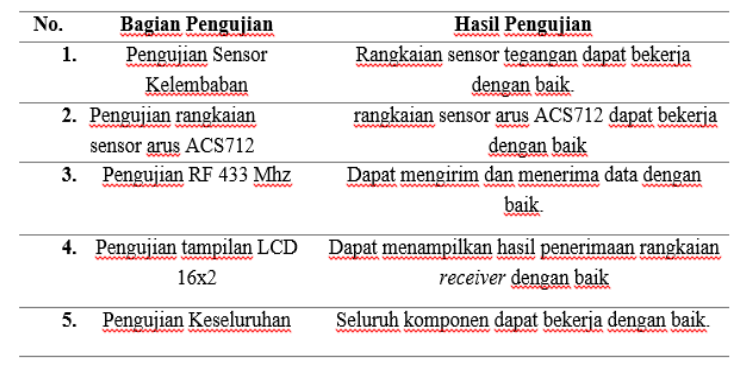

\section{Pembahasan}

\section{Pembahasan Sensor Kelembaban Tanah}

Dari hasil pengujian menunjukkan telah dilakukan oleh sensor kelembaban tanah dapat bekerja dengan baik..Serta transmitter RF 433 Mhz dapat mampu mengirim data. Pada rangkaian transmitter sensor kelembaban tanah dapat membaca kelembaban tanah dan selanjutnya data dikirim oleh rangkaian RF 433 MHz. kemudian data diterima rangkaian receiver $433 \mathrm{MHz}$ dan ditampilkan di LCD $16 \times 2$ yaitu 159 persen.

\section{Pembahasan Sensor Ultrasonic HC-SR04}

Dari hasil pengujian yang dilakukan dengan mengukur tinggi air pada miniatur sawah yang terhubung ke sensor ultasonic dan didapatkan hasil pengukuran yaitu tinggi $5 \mathrm{~cm}$ dan percobaan menunjukkan ketinggian $5 \mathrm{~cm}$ pada ukuran penggaris. Jadi Dari hasil pengujian yang telah dilakukan oleh sensor ultrasonic dapat bekerja dengan baik..Serta transmitter RF 433 Mhz dapat mampu mengirim data. dan selanjutnya data dikirim oleh rangkaian RF $433 \mathrm{MHz}$. kemudian data 
diterima rangkaian receiver $433 \mathrm{MHz}$ dan ditampilkan di LCD 16x2 yaitu $5 \mathrm{~cm}$.

\section{Pembahasan Modul RF 433 Mhz}

Dari pengujian didapatkan jarak transmisi optimal sejauh 16 meter dengan kondisi tanpa halangan yaitu pada catu daya transmitter 12 Volt dan kecepatan transmisi data 500 bps. Dalam satu kali transmisi sukses, jumlah data yang diterima akan persis sama jumlahnya dengan data yang dikirim. Sebaliknya, ketika jarak optimal terlampaui, maka tidak ada data yang diterima oleh bagian receiver.

\section{Pembahasan Pengujian Keseluruhan}

Dalam pengujian kali ini masih terdapat beberapa hasil yang kurang, yaitu pada pengiriman data modul RF $433 \mathrm{mhz}$ jarak maksimal yang dapat dijangkau 14 meter dan pada ruang terbuka.Jika pada terdapat halangan seperti ruang/ tembok pengiriman sulit untuk mengirim data.

Untuk pengujian sistem bisa dilakukan dengan menggunakan air dan tanah sebagai bahan yang diuji,untuk rangkaian transmitter yaitu sensor ultrasonic dan sensor kelembaban tanah yang dipasang di box miniatur.Untuk mendapatkan nilai tinggi dan kelembaban,kedua sensor dipasang pada miniatur sawah.

\section{KESIMPULAN}

Mengetahui cara membuat sistem irigasi pembibitan lahan padi berbasis atmega328 dan monitoring jarak jauh dengan radio frekuensi $433 \mathrm{mhz}$ dibuat dengan merancang alat mulai dari mikrokontroler, sensor ultrasonic, sensor kelembaban tanah kemudian dilanjutkan dengan mengirim transmisi data melalui modul RF $433 \mathrm{MHz}$ baik tanpa halangan maupun dengan halangan untuk ditampilkan di LCD 16x2. Sistm kerja alat ini yaitu mengaliri lahan padi dalam kondisi kering dengan memerintah pompa air agar tetap menyala yang diprogram melalui mikrokontroller dengan membaca sensor ultrasonic. Jika batas kerendahan air dibawah $5 \mathrm{~cm}$ pompa akan menyala dan jika sudah mencapai batas ketinggian $10 \mathrm{~cm}$ maka pompa air akan mati. Mengetahui cara membuat sistem irigasi pembibitan lahan padi berbasis atmega328 dan monitoring jarak jauh dengan radio frekuensi $433 \mathrm{mhz}$ dibuat dengan merancang alat mulai dari mikrokontroler, sensor ultrasonic, sensor kelembaban tanah kemudian dilanjutkan dengan mengirim transmisi data melalui modul RF $433 \mathrm{MHz}$ baik tanpa halangan maupun dengan halangan untuk ditampilkan di LCD 16x2. Sistm kerja alat ini yaitu mengaliri lahan padi dalam kondisi kering dengan memerintah pompa air agar tetap menyala yang diprogram melalui mikrokontroller dengan membaca sensor ultrasonic. Jika batas kerendahan air dibawah 5 $\mathrm{cm}$ pompa akan menyala dan jika sudah mencapai batas ketinggian $10 \mathrm{~cm}$ maka pompa air akan mati.

\section{Saran}

Mengembangkan dengan cara menambah sistem irigasi sawah secara otomatis untuk mempercepat pengerjaan sawah. Dapat dikembangkan melalui metode pengiriman wifi, sms dengan menambah solar cell jika bateray dalam kondisi habis.

\section{REFERENSI}

Djuandi, Ferri...PENGENALAN ARDUINO"2011

Dias Kusumo, Ridho. "Prototype pengendalian pintu air irigasi berdasar level air kelembaban tanah berbasis mikrokontroller". Tugas Akhir. Yogyakarta : Universitas Negeri Yogyakarta. 2011.

Herdiawan Yudistira. "Perancangan Dan Implementasi Alat Ukur Cos $\Phi$

Meter Digital Berbasis Mikrokontroller Atmega 328“. Bandar Lampung : C.V AMIR OFFSET. 2016.

Handoko, Bimo Ardi. "Sistem pengairan otomatis menggunakan mikrokontroller ATMega 8 berdasarkan sensor kelembaban tanah dan suhu tanah dengan mitode fuzzy inference system”.Tugas Akhir. Semarang : Universitas Semarang. 2009.

Mashuda. "Rancang Bangun Otomatisasi Filter Dan Tandon Air Rumah Tangga Berbasis Mikrokontroler Dengan Mengunakan Sel Surya". Skripsi. Lamongan :Universitas Islam Lamongan. 2016.

Musaharpa./2016/03/komunikasi-jarak-jauharduino.diambil pada tanggal 27 Februari 2017. 
Muhammad Khiabani Fakhri dengan judul "pengukur tinggi badan menggunakan sensor Ultrasonik berbasis mikrokontroler Atmega328 dengan output suara" :

Universitas Jember 2015

Nif'an, Ahmad. "Purwarupa kendali kanal irigasi sawah terjadwal berbasis mikrikontroller ATMega328”. Skripsi. Yogyakarta : Universitas PGRI Yogyakarta. 2016.

Nurhamim, Tristanto Didik. "Prototipe miniatur alat otomatisasi sistem irigasi pada tanaman melon". Tugas Akhir. Surabaya :

Universitas Narotama. 2013.

Sirait, Sudirman. "Rancang bangun sistem otomatisasi irigasi pipa lahan sawah berbasis tenaga surya". Jurnal. Bogor : Institut Pertanian Bogor. 2015

Wildan Panji Tresna "Rancang Bangun Sistem Radio Frequency sebagai Sumber Ion" 2001 